\title{
MULTILINGUAL LEGISLATION IN THE EUROPEAN UNION. EU AND NATIONAL LEGISLATIVE-LANGUAGE STYLES AND TERMINOLOGY
}

\author{
COLIN ROBERTSON ${ }^{1}$ \\ Colin.Robertson@consilium.europa.eu \\ Council of the European Union, Brussels, Belgium
}

\begin{abstract}
EU law is multilingual and multi-cultural. It is initially drafted in one language, now frequently English, often by non-native speakers and then translated into the other EU languages. Amendments may be proposed that are drafted in a different language. The result is a single multilingual text created in 23 language versions that are authentic within the context of the EU legal order. These circumstances have led EU legal language to develop its own terminology and legislative style as a separate genre.

One question is to identify different national cultural drafting styles and traditions that lie behind the creation of EU legislative texts and terminology. The Member State traditions vary, yet they merge in the EU legislative texts. In order to assist in the understanding of EU legislative texts, it is useful to reflect on how they are constructed and the features and requirements lying behind their creation, interpretation and transposition.

One approach is to consider a specific piece of EU text in a range of languages and consider how the text is reproduced in each language in terms of structure and terminology. Since the original draft is frequently made by non-native speakers and then translated into the other EU languages, which are bound by the structure of the base version, we obtain little information from it about divergent national linguistic and legislative methods. However, if the EU text is a directive which is transposed into national law, we should be able also to look at the national implementing legislation intended to implement the directive. The implementing texts are produced within the national legal context and, one assumes, aim at similar results, as laid down by the directive. Thus it could be expected that they should provide vehicles for study between the national systems and between each national system and the EU legal order. The paper explores these ideas to see where they lead.
\end{abstract}

Key words: multilingual legislation, national law, national language styles, environmental law, terminology

This paper derives from a presentation given at the Workshop on legal terminology LawTerm 2010, $1^{\text {st }}$ International Workshop on Legal Terminology hosted by the Department of English Language and Applied Linguistics, University of Łódź 28-29 May 2010 . It builds on ideas set out in several papers (Robertson 1999, 2009a, 2009b,

\footnotetext{
${ }^{1}$ The views set out in this paper are entirely personal to the author.
} 
2010a, and 2010b) and is based on personal experience working as a legal-linguistic expert in EU institutions, in particular the Council of the European Union. All comments are, however, purely personal.

\section{EU context}

The purpose here is to explore the nature of legal terminology of the European Union and its relationship to national legal terminology from the point of view of multiple languages and legal cultures. This information is important because EU legislative texts are being drawn up and negotiated on a regular basis for application and implementation in the national legal systems of the member states. In the case of directives under the Treaty on the functioning of the European Union ("TFEU") the EU texts require to be transposed directly into national law. This stems from the wording of the third paragraph of Article 288 of that Treaty which states:

"A directive shall be binding, as to the result to be achieved, upon each Member State to which it is addressed, but shall leave to the national authorities the choice of form and methods."

Implementation (also referred to as "transposition") frequently involves the drawing up of new national legislation. This situation creates a pragmatic context in which, on a regular basis, the EU terminology comes into contrast with the terminology of the national legal systems. The concepts in EU directives, expressed in all the language versions, fall to be transferred into the national legal system of each member state using terms selected for, and adapted to, each national legal context.

EU legislative texts are created within a multi-cultural and multi-lingual context.The linguistic regime is established pursuant to Article 342 TFEU which states:

"The rules governing the languages of the institutions of the Union shall, without prejudice to the provisions contained in the Statute of the Court of Justice of the European Union, be determined by the Council, acting unanimously by means of regulations."

The focus in this paper is on legislative and not court texts, so no mention will be made of the language rules applying to the Court of Justice. (For information: Court of Justice). The Council exercised its powers in Regulation No 1 determining the languages to be used by the EEC in 1958 (Regulation No 1). The act has been continuously updated and currently lists 23 languages. (For background: Interinstitutional Style Guide, paragraph 7.2.4). Each language version has the same formal status as an original ("authentic") text for the purposes of judicial interpretation.

This multilingual character has an impact on the terminology employed and the meanings which are attributed, often by means of express definitions, which can be explored and made clearer. In many cases EU legislative texts themselves reflect previously negotiated international agreements and this means that in addition to considerations of EU and national terminology one must frequently take into account the terminology of international texts which have been negotiated by parties both inside and outside the European Union, in the wider world, for example in the context of the World Trade Organization or the United Nations. This reflection leads to the thought that the 
terminology may be subjected to a number of influences and pressures, coming from different directions and that there may be an impact on meanings, and interpretations to be given, which can vary in subtle ways according to the particular context. The terminology can be seen as existing within a kind of 'matrix' of inter-connecting legal orders (national law, EU law, international law) and then it becomes a role for the courts and judges to steer a path through this matrix in individual cases as they come before them and to decide on the meanings to be given to specific terms and their application to the facts of cases brought before them for resolution.

It is difficult to understand implications without examples and so it is proposed in this paper to focus on an individual text. There are many possible candidate texts from the many fields of policy within which the European Union is active. Some fields are narrow and the range of terminology is specialised and focused, such as customs tariffs, value-added tax or social security (http://europa.eu/index_en.htm). In certain cases the EU texts exist in the form of regulations, for example customs tariffs (http://europa.eu/legislation_summaries/customs/111003_en.htm) and social security (http://ec.europa.eu/social/main.jsp?catId=867\&langId=en).

The second paragraph of Article 288 TFEU states:

"A regulation shall have general application. It shall be binding in its entirety and directly applicable in all member states."

That means that regulations resemble national laws and apply directly; logically there should be no national implementing legislation to transpose them, although in reality there are frequently incidental details which have to be determined such as naming the body which performs the role of "competent authority" and other practical matters. We can note in passing that this expression "competent authority" is frequently found in EU legislsative texts. It is an empty shell which indicates that a function is to be undertaken by a national body, but without naming them. The national legislator picks up the reference and gives, and is free to change, the identity for the national territory. Here we see how EU terminology is selected to be open and, in a sense empty, while being closed in terms of the range of possible meanings, with the member states filling in the precise meanings. Thus the EU (multilingual) text and the national acts become fused within a continuous discourse. EU legislative acts have to be seen within this wider discourse environment.

With an EU regulation, the logical corollary for EU terminology is that the EU terms apply directly in the national legal systems and carry a common EU meaning (except for the empty terms whose meaning is laid down in national law) backed up by judicial interpretation by the Court of Justice of the European Union in order to ensure uniformity. The EU terms should displace any competing national terms within the fields in which the EU regulations apply. For that reason regulations are the strongest form of EU legislative instrument. On the other hand, the terminology used in an EU text must come from somewhere and, while neologisms are created ("sheepmeat", "goatmeat"), it is frequently borrowed from national legal systems, or international law, together with adjustments and modifications in meaning to fit within the EU context, which is different from the national and internationallaw contexts. Regulations have the value of being generally precise and aiming at embracing all aspects of the domain covered, as befits a 
directly applicable law, but since the EU text displaces the national texts, it is not so easy to make thematic linguistic comaparisons between EU and national law texts. That makes them less useful if one wishes precisely to study these differences. On the other hand, with the EU directive there is a thematic continuity because the exercise is precisely to have a link between the EU directive and the national law texts that give effect to it. With these considerations in mind, it seems convenient to focus on the EU directive where national implementation is a specific requirement.

A few more preliminary observations may be made. All terminology to be found in EU legislative texts can be thought of as being legal simply by virtue of being included in a legal document, but if one looks closer, one can make distinctions between the types of terms used. Thus, there are terms which are used only for legal purposes; for example, names of EU legal instruments ("regulation", "directive", "statute"), names of courts ("Court of Justice", "General Court"), terms used in legislative or judicial procedures ("enter into force", "enact", "transpose"). To that we might perhaps add the terminology of certain specialised fields of law, in particular Contract Law as it is central to legal activity and social life ("breach of contract", "capacity to contract").

On the other hand, there are terms and expressions that appear in legislative texts but which also appear and have meaning in non-legal texts. This is typically the case for matters relating to policy domains and changes to be made within them by a legal act. Thus for example there are agricultural terms in texts dealing with agricultural matters (sheep, goats, beef, cereals...), economic terms for matters of an economic nature, medical terms for medical matters, and so on. That reflects the fact that terms in these fields are used predominantly in non-legal texts relating to the field in question, whether it be agriculture, economics, or medicine, to take the examples given. Thus, the terminology in legal texts varies according to the policy domains covered by the act, as well as the legal operations being performed by it. However, among EU legal texts which may contain some of the widest variations in range of terminology are perhaps those relating to environmental law, since environmental issues tend to be complex and frequently involve a balancing of many different considerations and policies. There are frequently conflicts of interest to be reconciled, such as economic and employment interests as opposed to preserving an undeveloped and wild landscape or clean air. These conflicts, and the compromises negotiated, are reflected in the legal texts, both in their structure and in the choice of terminology and they can be identified through a careful linguistic, and legal, analysis of the texts.

One of the earliest, and perhaps 'simplest' of the EU environmental law texts is the Wild Birds Directive and it is proposed to take this directive to serve as a practical example for exploring EU multilingual legal terminology, while at the same time using it to give a slight introduction to EU environmental legal texts. This reflects the dual nature of practical examples as a tool to illustrate theoretical points, while at the same time serving to convey information about the contents of the field in question. Before considering the directive, however, it is necessary to indicate the wider EU context in which it functions as a legislative text and which gives it its status and force. This reflects another feature of legal language, namely that any individual text invisibly reflects a whole mass of background legal rules and philosophy (and facts) that are present and influence the contents of the text but are not made explicit from the face of the text. It is only when one asks 'why?' repeatedly that these background factors start to 
emerge. For the EU drafter, the question arises repeatedly: de we need to mention a particular matter specifically or not.

Let's take a simple example, does one need to insert at the end of an EU instrument the words "This (act) shall be published in the Official Journal."? There may, or may not, be a need to publish which is connected to the facts, such as a decision addressed to only one person or a regulation addressed to all, but there is also a legal question. If the governing treaty and rules made under it already provide an obligation to publish, then this will happen without a need to say so explicitly in the act, so the sentence should be omitted and it would be inappropriate to include it. On the other hand, if there are no such rules but there is a need (for whatever reason) to publish, then the sentence should be included if publication is intended. That is the viewpoint of the drafter who can only know what to draft by knowing other legal texts. On the other hand, from the viewpoint of the reader, the presence or absence of this sentence is a sign regarding the background legal situation; so it is possible to obtain deeper levels of information working backwards from the face of the text, provided one knows the logic of the system.

To summarise, while a lot of information can be obtained from a linguistic study of a legal text by itself, the reality is that factors governing its structure lie outside it and the text can only be understood fully if all of these elements are identified. That means specialist knowledge; not only specialist legal knowledge, but also knowledge of the policy field in question. That means placing the text in context and, for legal acts, it means that inter-textuality and the link to other texts in the legal system, and the thematic domain, is paramount. We can see that in the EU legal context as regards the Wild Birds Directive. This applies to each language version of the EU legal act.

\section{EU Wild Birds Directive}

With those thoughts in mind we can move to consider the example of the EU Wild Birds Directive. This was one of the first environmental directives and dates from 1979. It can be noted in passing that much of the legislation in the member states has its origin in EU legislation. (http://ec.europa.eu/environment) The original text has been amended and recently a new codified/consolidated text has been issued. However, before citing the title, it is worth making a short terminology detour becasue we have here an example of the way in which EU terminology in English has diverged from classic English terminology. In classic English legal usage, when a series of legislative texts in which a base text has been amended with insertions and deletions is tidied up by producing a new text inserting all the additions and changes, this is called "consolidation". However, in EU language the exercise is termed "codification". Classic English usage reserves "codification" for organising or collecting together laws, rules or procedures into a system or code which usually entails rewriting in a different way and setting out a series of principles, like the French Code Napoleon (Code civil) or the British Highway Code. However, in the EU context the term "codification" (in French) could be reproduced closely across the various languages and thereby reflect a singular EU concept underlining the conceptual singularity of multilingual EU law. In the process, the English terminology was aligned on the French. This is an example of the way in which EU language, for all language versions, can depart from the national language and means 
that one can think of each EU language as being like a 'dialect' form of the language in question.

With respect to the English language, which tends now to be the main language for negotiation, one can add some additional reflections. The original English versions of the EEC texts were historically translations, principally from French, and that in effect means that they were a form of Civil Law English; the subsequent English EU texts have been built on that Civil Law foundation and this influences both terminology and drafting style. For example, the Treaty establishing the European Coal and Steel Community was authentic only in French; the EEC and EAEC treaties were originally framed in four languages: Dutch, French, German, Italian. This can be seen from the final articles of each treaty in its original form. From a legal point of view the form of drafting of Common Law English legislative texts differs from that of Civil Law traditions; notably through a Common Law tendency towards more precision and detail as opposed to a broader and more general Civil Law exposition of rules and principles. (Gotti 2008 ) However, the nature of the field and policy to be implemented also has a bearing: a text on tax will inevitably be detailed and precise whereas a text on culture may be less so.

Taking all the individual elements relating to the way in which EU legislative texts are constructed, combined with Civil Law English and a harmonising of terms across languages to reflect conceptual singularity, it becomes possible to analyse and understand why and how EU texts look and feel odd and unfamiliar to native speakers in the member states-in all the languages. This was discussed for EU English in Mollin 2006. And we have not even mentioned the economic orientation of EU legislative texts and market theory.

The full title of theWild Birds Directive is:

"Directive 2009/147/EC of the European Parliament and of the Council of 30 November 2009 on the conservation of wild birds (codified version)."

For reasons of space, it is not possible to reproduce the full text of the Directive here, nor to analyse all its contents in all languages. The present purpose is oriented towards legal terminology and exploring issues relating to linguistic style across and between languages. Are there differences in drafting style and use of terminology between languages? Can we make use of the different language versions of EU legislative texts as a means for exploring these differences? And what happens when it comes to transposition? The advantage of using EU texts to work on is that they are easily accessible from the Europea website http://europa.eu. To explore the issues it is proposed to take a selection of texts from different parts of the Directive and to explore four language versions which can be taken as a small sample chosen to cover most of the main linguistic family groups among the EU languages: English, French, German, Slovak.

The Directive, in summary, has as its purpose to enhance the conservation of wild birds. The text sets out provisions on their protection, management and control. It provides for the protection of eggs, nests and habitats and sets out the duties and obligations to be complied with by the member states. There are also derogations, notably in relation to hunting issues. Different rules apply to different species and there are lists in annexes which make clear which rules apply to which species. Lastly, the 
Directive contains provisions on the review of the Directive, on its amendment and committee procedures connected with the functioning of the Directive.

In statistical terms, linked to the structure of the Directive, we can note that there are five structural parts, which is typical for EU directives: title, citations, recitals, articles, annexes. Each part has a precise role in the text and the drafting is linked to role and is highly stylised in presentation and formulation. The title makes clear the subject matter (conservation of wild birds), the type of act (directive), the authors (European Parliament and Council) and the date of adoption (30 November 2009). The citations indicate the treaty base and formal procedures connected to the preparation of the act. Here we note that it was Article 175 of the EC Treaty, predecessor to the TFEU. The TFEU Article numbering is different and we need to know that by virtue of the Lisbon Treaty and its Table of Eqivalences, the relevant Treaty base is now Article 192 TFEU. The recitals introduce the act, explain its purpose and what it is seeking to achieve, as well as justifying it and giving reasons. (in French: "motivation"). The articles contain the body of the act, the operative part lenacting provisions; (i.e. the commands and instructions. The annexes contain technical matters which are usually too lengthy to include conveniently in the body of the text.

Typically, annexes contain language which is not legal, for example in this Directive there are lists of birds, using their scientific names. The Wild Birds directive is short: it has four citations, eighteen recitals, twenty articles and seven annexes. Guidance on EU legislative drafting is provided inter alia in the Interinstitutional Style Guide, Interinstitutional Agreement of 22 December 1998 and the Joint Practical Guide. (See also: Gallas 1999, Morgan 1982, Robinson 2008).

To illustrate the language style of different parts of the act we can select an example from the recitals and an example from the articles, in each case in the four languages proposed. Thus, Recital (9) of the Directive states:

\section{English}

"In order to prevent commercial interests from exerting a possible harmful pressure on exploitation levels, it is necessary to impose a general ban on marketing and to restrict all derogation to those species whose biological status so permits, account being taken of the specific conditions obtaining in the different regions."

\section{French}

"Pour éviter que les intérêts commerciaux n'exercent une pression nocive éventuelle sur les niveaux de prélèvement, il est nécessaire d'instaurer une interdiction générale de commercialisation et de limiter toute dérogation aux seules espèces dont le statut biologique le permet, compte tenu des conditions spécifiques qui prévalent dans les différentes régions." 


\section{German}

"Damit sich kommerzielle Interessen nicht negativ auf den Umfang der Entnahme auswirken können, sollte die Vermarktung allgemein verboten werden und jedwede Ausnahmeregelung ausschließlich auf diejenigen Vogelarten beschränkt werden, deren biologischer Status dies zulässt; hierbei sollte den besonderen Gegebenheiten in den verschiedenen Gegenden Rechnung getragen werden."

\section{Slovak}

"Na to, aby sa zabránilo obchodným záujmom vyvinút' možný škodlivý tlak na stupeň využívania, je nevyhnutné zaviest' všeobecný zákaz obchodovania a obmedzit' všetky výnimky len na druhy, ktorých biologický stav to umožňuje, berúc do úvahy špecifické podmienky v rôznych oblastiach."

We can reflect on these texts, note their features and ask some questions. Which text reads most smoothly? Which looks like it might have been the original, and why? Does each text convey the same information? Do they all follow the same syntax structure? Which domains do the terms come from - law, economics, biology? Do the equivalent terms used each have the same meaning in each language. Here we can be asking whether the equivalent words in the different language versions have the same EU meaning and also whether for each language the words would have the same meaning if used in a national context. In other words, how would a native speaker who knew about national law but not about EU law read and interpret the terms? This is a fundamental issue as it touches on the comprehensibility of EU texts by citizens unversed in EU law. Another way of framing the question is to ask whether the meaning of each term in each language version is specific to the EU context or goes beyond it, which was touched on previously.

If we look at the texts, we see first that each of them comprises a single sentence. This reflects the basic synoptic approach of EU texts: the language versions match each other structurally and in content. Three language versions begin with a subordinate clause, followed by a main clause and end with a qualifying phrase. The German version, however, departs from that and has a more complex structure. In particular a semi-colon is inserted between "zulässt" and "hierbei". This is a sign that the text is a translation and that the translator preferred not to follow the same syntactic structure as the source language version. Use of the semi-colon allowed the sentence format to be preserved while expressing the same message. We can infer that if the text had been originally drafted in German, it might have been formulated differently.

Each text is introduced by a conditional expression. ("In order to prevent ...", "Pour éviter que ...", "Damit ...", "Na to, aby..."). The versions then follow their own grammatical forms which differ. In the main clause, we can observe the use of conditional verb forms ("it is necessary to", "il est nécessaire $d$ ", "sollte", "je nevyhnutné"). Modern EU legislative texts in English typically use the term "should", or an equivalent expression, as here, in recitals to introduce topics and to act as a marker, or sign-we are also in the field of semiotics-that the text of a recital is not intended to be an enacting provision (Interinstitutional Agreement, guideline 10), which is a role reserved for articles (guideline 12). The language is stylised and brings together in one sentence a 
range of topics that in ordinary language might be expressed in more than one sentence. It is language that introduces the articles and provides reasons and justifications, as succinctly as possible. It is not laying down a rule. If we look at the terminology in English, the concepts are not particularly legal: (commercial interests, harmful pressure, exploitation, general ban, marketing, derogation, species, biological status, specific conditions, regions). They are a mixture of economic and biological terms. They belong to the wider category of non-legal terms that overlap with other types of text discussed above.

A further step could be to analyse the language versions to see if each carries exactly the same nuances. This takes us into mulilingual interpretation. However, recitals are ancillary to the articles and so, to identify the action intended, one should first read and interpret the articles themmselves and then, if there are problems in understanding what is intended, one can look back again at the recitals to see what were the reasons for the act and the articles in question; in this way the recitals become an aid to interpreting the articles and the directive generally. This is legal method; there is a legal way of reading the texts. At first sight the texts here seem to match and it is not proposed to proceed further on this point.

What inferences can be drawn? Each language seems to use the grammar, spelling and writing rules of the (national) language, but with adaptations to the EU context. The terminology seems fairly standard and part of national language too. The syntax is specific to the EU context; although maybe national legal texts are written in the same way for some language versions. If we hope to find out more about differences between drafting in the different languages by using EU texts as a source study, it is becoming evident that there are drawbacks; we cannot be sure how far the language versions are expressing themselves freely and naturally and how far they are being forced into a predetermined rigid mold, created by the base language version (whichever it may be). The example of the semi-colon in the German version, taken together with the rest of the text suggests the latter. That is consistent with the ambition of EU legislative texts to present the same information in the same way in all languages and therefore to demonstrate unity in approach across all language versions. But it makes life complicated for translators and revisers at times.

Let's now take an example of an article, to compare language style in the same four languages. Article 2 of the Wild Birds Directive states:

\section{English}

"Member States shall take the requisite measures to maintain the population of the species referred to in Article 1 at a level which corresponds in particular to ecological, scientific and cultural requirements, while taking account of economic and recreational requirements, or to adapt the population of these species to that level."

\section{French}

"Les États membres prennent toutes les mesures nécessaires pour maintenir ou adapter la population de toutes les espèces d'oiseaux visées à l'article 1 er à un niveau qui corresponde notamment aux exigences écologiques, scientifiques et culturelles, compte tenu des exigences économiques et récréationnelles." 


\section{German}

"Die Mitgliedstaaten treffen die erforderlichen Maßnahmen, um die Bestände aller unter Artikel 1 fallenden Vogelarten auf einem Stand zu halten oder auf einen Stand zu bringen, der insbesondere den ökologischen, wissenschaftlichen und kulturellen Erfordernissen entspricht, wobei den wirtschaftlichen und freizeitbedingten Erfordernissen Rechnung getragen wird."

\section{Slovak}

"Členské štáty prijmú opatrenia potrebné na zachovanie populácie druhov uvedených $\mathrm{v}$ článku 1 na úrovni, ktorá zodpovedá najmä ekologickým, vedeckým a kultúrnym požiadavkám, berúc do úvahy aj hospodárske a rekreačné požiadavky, alebo na prispôsobenie populácie týchto druhov tejto úrovni."

We can ask questions about the articles similar to those we asked about the recitals. The example proposed here is simple and there is a single sentence for the article. The subsequent articles in the Directive are more complex; some texts have extremely complex and subtle articles, and interpretation becomes difficult and complex, but the aim here is to try and remain on a simple level. The Article is essentially a single sentence, with qualifying elements, or at least it is in the French version. It reads smoothly: "... prennent ... pour maintenir ou adapter ... qui corresponde ...compte tenu...". The English version is more awkward, in particular at the end: "...shall take ... measures to maintain ... which corresponds ... while taking account ... or to adapt...". The phrase "or to adapt..." begs the question of what it is an alternative to? We need to search the sentence for clues, or signs, as to meaning, which cover topics such as: grammar, syntax, logic, our knowledge of how the language works and our knowledge of the world ("commonsense"). The French version did not raise this doubt. Taking a multilingual approach we can search for meaning from the French text as well as the English and we can find an answer; but is it the correct one, that is to say intended, and which fits within the whole scheme of the act? For the present purposes, we might suspect that if the English text had been drafted in a national English language way from scratch, it might have been structured differently.

We can now look at the German version: "...treffen... um ...zu halten oder ...zu bringen, der ... entspricht, wobei ... getragen wird." The doubt we had for the English version is clarified, but the structure of the sentence is more complex, reflecting German syntax. The Slovak version seems to follow the English because it also contains the alternative at the end: "...prijmú ... na zachovanie... ktorá zodpovedá...berúc do... alebo na prispôsobenie...." That suggests it may be a translation from the English, since Slovak accession came later, and if so one has a difference betwen the language versions; if we assume that the French version was the source and the German and English were translations, as seems lilely for a text from 1979, as well as from the evidence of the versions, then there is a single step remove between source and target langauge for those texts, but if the Slovak is a translation from the English, then there is perhaps a second step remove from the original source. (This is a consideration when a new language is being added to the EU acquis and implies a constant checking of all language versions.) We can turn now to the terminology of the article. 
The text contains a command. This is reflected in English by the modal "shall" ("Member States shall take the requisite measures"). That conforms to classic English legal usage, although it is changing. (Williams 2006, 2008). In French ("prennent"), German ("treffen") and Slovak ("prijmu") it is a present tense indicative. That is believed to reflect national styles. There is however a residual ambiguity between statement of fact and statement of command, which "shall" avoids. The context should make clear what is intended. In terms of drafting style, the article looks like Civil Law drafting style (Gotti 2008), in view of the broad and general wording. The terminology is a mixture of domains, even in this short article. There are legal terms ("shall take", "measures", "referred to in Article1"), scientific terrms ("population", "species", "ecological", "scientific") and economic terms ("economic"). Another feature of the article is the use of references to other texts in order to avoid lengthy repetitions; the expression "referred to in article 1" performs this function, as do references to annexes elsewhere in the text. This is a typical feature of legal texts.

One language serves as a model (Robertson 2010a), the others follow that model. Sometimes, a translation may serve as a model for yet a further translation, in particularly when new languages are added when new states become members; we noted that for the Slovak version of Recital (9). Structure and terminology are set in the base language version and other languages adapt to them as well as they can; if necessary new terms are created. The language versions use national language, but not necessarily in the way it would be used in a national context. The EU context shapes and determines all the language versions structurally, syntactically, grammatically and sometimes for spelling, for example words in English ("cooperate" rather than "co-operate").

However, EU base texts are often drafted and negotiated by non-native speakers which means that terms and syntax may not exactly match native usage; that can create problems for translators who have been highly trained in the native terminology and syntax as it gives rise to an element of uncertainty as to the exact intended meaning of the text. It also means that sometimes texts may be grammatically correct but stylistically not in accordance with native usage, and there is some evidence of that in the examples studie above. Translators have to adapt to that; so do users of the texts. Yet strange wording, and ambiguity, is sometimes intended by the negotiators as the only means by which they can agree on a joint text, but then it means that they may be handing over the power of decision regarding meaning to the courts, in the event of a dispute. Another aspect is that some languages have difficulty handling ambiguous sentences and are forced to make interpretations as to meaning, which may be intended or not; German and Slavic languages are examples here, because of their systems of inflection. Lastly new terms are continuously being created and used in EU texts and frequently they are hard to translate. A favourite example is "gender mainstreaming".

From the examples looked at, it looks as if it may not be possible to make clear identifications as regards the different linguistic and drafting styles of the various languages from EU texts alone, since the language versions are so closely bound together. However, it is not the case that the language versions do not reflect national styles and methods at all; they do. The EU terminology does not come from nowhere; it is derived from national legal and linguistic methods and styles, for example the use of the modal 'shall' in English is drawn from national drafting practice. But it is difficult to be able to identify clear dividing lines in view of the hybrid nature of EU legislation and 
the needs of multilingual drafting. To go further in studying differences in national linguistic practices, one should look at the various national pieces of legislation that have been produced, for example, in implementation of the EU Wild Birds Directive.

Conceptually, one could imagine that one starts with a single EU text in 23 languages, containing a single (in theory) set of policy instructions for implementation in all the member states according to their own domestic methods. One would then expect a single piece of national legislation dealing with all the issues together in a neat way, matching the Directive. That would mean that we would be able to obtain clearer information about national drafting styles and make comparisons. The approach would be rather like the studies of international arbitration law texts (Bhatia 2008). The bottom line is that to go further into the national context requires going into issues relating to transposition of EU directives. Is it possible to match up the EU directive with the national laws? Is transposition done on a one to one basis? That is to say, one EU directive transposed into one national law, so we can line up and compare all the national language versions?

\section{Transposition from $E U$ into national law}

Let's say a few more words on the EU directive. Of the five parts of the text (title, citation, recitals, articles and annexes) we have considered one title, one recital and one article. We have not looked at the annexes which are technical and do two things: first, they indicate the bird species covered by particular provisions of the act and the linkage of particular obligations to particular member states, for example as regards hunting rights. Secondly, because the text is a "codified" text which consolidates pervious texts into a single act, there are annexes that indicate the past texts of the act, the deadlines for transposition and the carry-over of old articles to the new text ("table of equivalences"). As regards the citations we can note that they have no verbs. They indicate the legal foundation of the text but do not by themselves undertake an action. For example, the first citation in the Wild Birds Directive in English is: "Having regard to Article 175(1) of the Treaty establishing the European Community" (Pre-Lisbon treaty text).

A directive may have just a few articles or a hundred of them (with a matching variation in the number of recitals) in a complex text. There may be higher level divisions grouping articles together according to themes under chapters, sections or parts, and there may be many lower level divisions of the articles where issues are complex and subdivisions into paragraphs, subparagraphs and points are required. The central element is the article in an EU text which sets out a unit of information. Typically articles are imagined as commands and use language of obligation, whether it be to confer rights or duties (conferring a right implies an obligation by others to respect it). The language versions are intended to convey the same information and are aligned to that end. Analysing the texts leads to questions about translation strategies, styles and equivalence of terminology. A certain amount of information about national legal language differences is obtained.

The EU directive can be thought of as an instruction to member states to change their laws in particular ways. It is legally binding as to result but the method is left to the member states. What does that mean in practice? We will stay with Wild Birds 
Directive. Two EU terms of art in this area are "transpose" and "harmonise". The former denotes the carrying over and implementation of obligations, the latter the making of national laws of the member states the same or similar. Transposition takes place from the EU context towards and into the national context and the result is that the laws of the member states become harmonised.

Transposition implies: first, analysing the directive, interpreting it, understanding the intentions, objectives and methods, deconstructing it, discarding purely EU elements (such as EU committee procedures and EU review arrangements); second, making an analysis of national law point by point for each element in the directive and identifying whether the obligation is already respected or requires new national laws and if so what; third, constructing national texts within the national legislative framework in accordance with national rules on drafting (intertextually) in order to implement the EU policy.

The actual task of transposition is frequently complicated and involves many decisions. For example, whether simply to repeat the wording of a directive as a block of text embedded into national law, or whether to make a new detailed enactment which deconstructs every EU element and reconstructs them in specialised and technical ways, thereby departing radically from the appearance of the EU directive. Or something in between. Are the obligations already implemented in national law, so that no further action is needed? EU terms have EU meanings; can the same words be used? Do the same words have a sufficiently similar meaning so as to be capable of being used without attaching special definitions to them? Which language versions to work with? Do they all convey the same meaning? It is at this point that divergences in EU languages will start to have effects if national authorities take different versions and interpetations of the EU texts in order to adapt the national law. There is also a risk of the national legislator attaching national law meanings to the EU text.

The national drafter must think about many things. The national legal act must conform to the national styles, methods and procedures. For example, the EU text, especially if a treaty text may require changes to the national constitution; or it may just be a case of deciding whether implementation is to take place by means of a higher ranking law or a lower ranking implementing regulation. There is often a broader national policy dimension and the EU implementing part may be just one element of a wider set of changes being made at the national level for other reasons. The national drafter has to decide on the structure of the national act and on its terminology, which must be adapted to the national legal system. EU terms and expressions have to be adapted and fitted into the national context. The EU message has to be understood clearly so that it can be translated into the national context and since the EU text is multilingual all the language versions should logically be consulted. However, the national drafters will not understand all the language versions, so there is a risk of missing something.

What happens if they discover slight divergences? We saw a difference in presentation between language versions of Article 2 of the Wild Birds directive. Yet divergences can occur within the same language over time. Take the example where an EU text is written in the 1970's and amended several times in following decades. An English drafter studies the English versions and finds that there have been changes in the terms and expressions used in succeeding versions and worries whether there is a change of meaning for the terms. However, an examination of the French versions of the same texts may reveal that the same terms and expressions were used and in repeated each 
time in French. So there is no problem for the French version. The French may have been the base language used for negotiation and the English may have been a translation. The policy remained constant. However, translation is not a purely scientific activity and English in particular is a language with many synonyms; different translators can choose different terms for the same source language word. The role of EU legal-linguistic revision is to spot and align these inconsistencies but sometimes they are not detected or may not be changed. The important point is that there can be an element of 'fuzziness' at times in the EU texts. This arrives first from hybridity stemming from intercultural negotiation and secondly from slight translation variations over time, or a desire to switch terminology, which also sometimes happens in the light of a better understanding of what is involved. These factors need to be built into the process of reading and interpreting the EU message.

\section{National law context}

If we wish to proceed further in making comparisons between different languages and between EU and national language and the process of transposition, we need to move into the national law context. In every case, national law is complex; there are highly developed political and administrative structures and levels (federal, länder/regions, local level). This affects who makes the acts as author. There are many domains of law: civil, criminal, property, contract, administrative, etc. There are many policy fields: competition, energy, finance, budget, family, social security, environment, etc (domains which are often codified, depending on the system). There is also 'intertextuality' in the shape of a network of interconnecting laws, court judgments, etc. There is also substantive law and procedural law; in general the EU texts aim at changing the rules of substantive law, but it may be that new methods and processes, in the form of procedures, are to be introduced. Law is also hierarchical and transposition may involve interventions at different levels.

We can return to the example of the wild Birds Directive and consider its transposition into the law of the member states. In theory we should be able to trace the EU obligations and language obligations through into the national texts and identify the linguistic and terminology choices. However, in order to do so we need first to find out which texts are relevant. That involves making searches and requesting information. Internet searches for implementation of the Wild Birds directive reveal that this task is not easy to achieve. For the UK, there are a range of texts and these include for England: The Wildlife \& Countryside Act 1981 (as amended), The Conservation (Natural Habitats \& c.) Regulations) 2010 (as amended), Offshore Marine Conservation (Natural Habitats \& c.)Regulations 200, and other legislation related to the uses of land and sea. (http://www.jncc.gov.uk/page-1373). French environmental law is codified and set out in the Code de l'environnement (Version consolidée au 17 novembre 2010). In Germany there is the Gesetz über Naturschutz und Landschaftspflege. Slovakia has ZÁKON z 25. júna 2002 o ochrane prirody a krajiny.

If we wish to proceed further, we need to become more specific and selective. We need to focus on a particular issue and see how that one issue was handled in each system and study the context. At this initial stage, we are not sure whether we have the 
right texts or whether there are other texts that cover wild birds in some way. The list of implementing acts for England suggests that the theme of wild birds may occur in different domains of the national legal system. Yet we can already sketch out some different contexts: on the one hand series of narrowly focused laws that deal with, inter alia, wild birds and on the other hand a very broad code that covers a large range of topics and somewhere embedded there are provisions that relate to wild birds. But a perusal of the French Code de l'environnement soon reveals a highly structured and internally organised set of information. That means that if one wishes to understand the rules applying to wild birds one must first master the theory and method lying behind the construction of the code. It is a very specialised text. As against that, the provisions applying in the other countries seem to be more specific to particular themes. To reflect further on the relationshp between EU and national legislative styles and terminology we need not only linguistic knowledge but legal knowledge about the ways in which the texts have been constructed and how they should be read. In view of the extent and range of national law, we can expect terms to have narrow and very precise meanings, especially so, since each of the countries mentioned makes its laws in a single language and in the context of a single legal system which allows a high level of control. Perhaps it is that which constitutes the biggest difference between EU and national legislativelanguage styles and terminology.

\section{References}

Bhatia, Vijay, Christopher Candlin \& Maurizio Gotti. "Introduction”. 2008. (also eds). In Language, Culture and the Law: The Formulation of legal Concepts across Systems and Cultures. Linguistic Insights. 64. Bern: Peter Lang. 9-20.

Code de l'environnement (Version consolidée au 17 novembre 2010) (http://legifrance.org/affichCode.do?cidTexte=LEGITEXT000006074220\&dateText $\mathrm{e}=20101121$ \&categorieLien $=$ cid $)($ accessed 25.11.2010)

Court of Justice. http://europa.eu/institutions/inst/justice/index_en.htm and http://curia.europa.eu (accessed 24.11.2010)

Directive 2009/147/EC of the European Parliament and of the Council of 30 November 2009 on the conservation of wild birds (codified version) (OJ L 20, 26.1.2010. 7).

See generally: http://ec.europa.eu/environment/nature/legislation/birdsdirective/index_en.htm (accessed 25.11.2010)

Gallas, Tito. 1999. "Coredazione e Traduzione Giuridica nella Legislazione Multilingue, in Particolare Quella Comunitaria". 43 Quaderni di Libri e riviste d'Italia, la Traduzione, Saggi e documenti (IV), 135-147.

Gesetz über Naturschutz und Landschaftspflege (Bundesnaturschutzgesetz - BNatSchG) (http://archiv.jura.uni-saarland.de/BIJUS/umwelt/ Text in German and French). (Accessed 25.11.2010).

Gotti Maurizio. 2008. "The Formulation of Legal Concepts in Arbitration Normative Texts in a Multilingual, Multicultural Context". Bhatia, Vijay, Christopher Candlin \& Paola Evangelisti Allori (eds). In Language, Culture and the Law: The Formulation of legal Concepts across Systems and Cultures. Linguistic Insights. 64. Bern: Peter Lang. 23-45. 
http://europa.eu (accessed 24.11.2010)

http://ec.europa.eu/enlargement (accessed 24.11.2010)

$\mathrm{http}: / /$ ec.europa.eu/environment (accessed 24.11.2010)

http://ec.europa.eu/environment/nature/legislation/birdsdirective/index_en.htm (accessed 24.11.2010)

http://europa.eu/index_en.htm (accessed 24.11.2010)

http://europa.eu/legislation_summaries/customs/111003_en.htm (accessed 24.11.2010)

http://ec.europa.eu/social/main.jsp?catId=867\&langId=en (accessed 24.11.2010)

http://www.jncc.gov.uk/page-1373 (accessed 25.11.2010)

Interinstitutional Agreement of 22 Decenber 1998 on common guidelines for the quality of drafting of Community legislation (OJ C 73, 17,3,1999.1) (http://eurlex.europa.eu/LexUriServ/LexUriServ.do?uri=CELEX:31999Y0317(01):EN:NOT) (accessed 24.11.2010)

Interinstitutional Style Guide. http://publications.europa.eu/code/en/en-000500.htm (accessed 26.11.2010)

Joint Practical Guide for the Drafting of Community legislation. Luxembourg. Office for Official Publications of the European Communities. 2003.http://eurlex.europa.eu/en/techleg/pdf/en.pdf (accessed 24.11.2010)

Mollin, Sandra. 2006. "Euro-English: Assessing Variety Status". In Language in Performance. Tübingen, Günter Narr Verlag.

Morgan J.F. 1982. "Multilingual Legal Drafting in the EEC and the Work of Jurist/Linguists". Multilingua I-2 . 109-117.

REGULATION No 1 determining the languages to be used by the European Economic Community. (O J L 17, 6.10.1958. 385). Updated version at http://eurlex.europa.eu/LexUriServ/LexUriServ.do? uri=CONSLEG:1958R0001:20070101:EN $: P D F$

Robertson Colin. 1999. "Multilingual Law: A Framework for Understanding" In Language for Special Purposes Perspectives for the new Millenium, Vol.2. 697- 703. Tuebingen: Gunter Narr.

- 2009a. "Multilingual Law: What is it? How is it made? How is it Used and Applied? (with reference to EU practice)". Sočanac, Lelija, Goddard, Christopher, Kremer, Ludger (eds). In Curriculum, Multilingualism and the Law. 373-395. Zagreb: Globus, 2009.

- 2009b. "LSP and EU Legal Language". XVII European Symposium on LSP, 17-21 August 2009. Aarhus. Denmark. Extended paper to be published on-line at the Symposium website: $<$ http://www.asb.dk/article.aspx?pid=20015>.

— 2010a. "Legal-linguistic Revision of EU Legislative Texts". In Maurizio Gotti \& Christopher Williams (eds). Legal Discourse across Languages and Cultures. 51-73. Bern: Peter Lang.

- 2010b. "EU Law and Semiotics". International Journal for the Semiotics of Law. Dordrecht. Springer. 145-164.

Robinson, William. "Drafting of EU Legislation: A view from the European Commission”. Rivista di Diritto Pubblico Italiano, Comunitario e Comparato. 2008. $<$ http://www.federalismi.it> (accessed 24 November 2010) 
Williams Christopher. 2006. "Fuzziness in Legal English: What Shall we Do with Shall?". In Wagner, Anne \& Cacciaguidi-Fahy, Sophie (eds). Legal language and the Search for Clarity. Bern: Peter Lang.

Williams Christopher. 2008. "Crossovers in legal cultures in Westminster and Edinburgh: some recent changes in the language of the law". In ESP Across Cultures. 2007 vol. 4:101-118. Bari: Graphis.

ZÁKON $z \quad$ 25. júna $2002 \quad o$ ochrane prírody a krajiny (http://www.sopsr.sk/natura/dokumenty/legislativa/eu/Zakon543.doc). (Accessed 25.11.2010) 